\title{
Influence of Bed Geometry on the Drying of Skimmed Milk in a Spouted Bed
}

\author{
Maisa Tonon Bitti Perazzini, Fábio Bentes Freire, José Teixeira Freire \\ Department of Chemical Engineering, Federal University of São Carlos, São Carlos, Brazil \\ Email: maisatbp@gmail.com, bentes@ufscar.br, freire@ufscar.br
}

Received 6 August 2015; accepted 7 October 2015; published 12 October 2015

Copyright $@ 2015$ by authors and Scientific Research Publishing Inc.

This work is licensed under the Creative Commons Attribution International License (CC BY). http://creativecommons.org/licenses/by/4.0/

(c) (i) Open Access

\begin{abstract}
In this present work, the fluidynamic and drying process of skimmed milk in conical and conicalcylindrical spouted bed was analyzed as a function of different bed geometry and operating conditions. It used three internal cone angles $\left(45^{\circ}, 60^{\circ}\right.$ and $\left.75^{\circ}\right)$, different loads of inert particles $(1.50$, 3.00 and $4.50 \mathrm{~kg}$ ) and a fixed static bed height $(20.50 \mathrm{~cm})$. Polyethylene particles of $4.38 \mathrm{~mm}$ of diameter and $930.50 \pm 0.3 \mathrm{~kg} / \mathrm{m}^{3}$ of specific mass were used as inert particles. An artificial neural network model was trained to predict the peak pressure drop and the minimum spout velocity from an experimental data bank. The experimental results showed a significant effect of geometric characteristics of the bed on fluidynamics parameters. It was also observed for the operating conditions that conical spouted bed and cone angle of $45^{\circ}$ were more suitable for drying skimmed milk. The neural network provided predictions in good agreement with experimental data.
\end{abstract}

\section{Keywords}

Cone Angle, Bed Geometry, Bed Configuration, Inert Particles, Neural Network

\section{Introduction}

Several studies have been conducted to investigate the operating conditions on the fluidynamics and drying of pastes in a spouted bed. Mathur and Epstein [1] reported that the minimum fluid velocity at which a bed would remain in the spouted state depended on solid and fluid properties on the one hand and bed geometry on the other hand. Olazar et al. [2] conducted a study using contactors with different geometries, solids of different characteristics and with wide range of air velocity. The authors observed that there were limits for cone angle, $D_{0} / D_{i}$ and $\mathrm{D}_{\mathrm{o}} / \mathrm{d}_{\mathrm{p}}$. From that, it was obtained the design parameters for the stable operation in a spouted bed. Olazar et al. [3] investigated the effect of the operating conditions (base angle, air inlet diameter, stagnant bed height, particle diameter and air velocity) on the fountain geometry. It was seen that the contactor base angle had a major 
incidence on the fountain geometry. San Jose et al. [4] reported that the angle cone had significant effect on the air velocity, the particles trajectory, and height of the font.

Pham [5] verified the existence of stagnant regions and the difficulty of particles circulation in the annular region with inserting pastes in bed. Thus, it was concluded that the pastes significantly changed the fluidynamics parameters as well as the solid and fluid circulation patterns. Medeiros et al. [6] investigated the influence of the chemical composition on the spouted bed performance in drying pulps of tropical fruits. The authors found that the presence of pulps with high concentrations of sugars provoked problems of instability in the spout, while the presence of fat favored the bed dynamic. Recently, Nascimento et al. [7] studied different concentrations of milk fat and found that the pulp composition also affected the process, since the absence of fat in skimmed milk caused significant changes in the flow of inert, and therefore provided increase expressive values of pressure drop.

The context presented shows that there are several factors affecting the fludynamic parameters and drying process in spout beds. However, it is difficult to get a good prediction of minimum spout velocity, pressure drop behavior and evaporation capacity of the equipment as a function of different experimental conditions once there are some gaps in the information provided by literature. In general, the analysis of the influence of bed geometry is done in dry beds and for operations using pastes the bed geometry was fixed. In order to improve knowledge in this subject, the experimental analysis was divided in three stages: first it was performed the determination of fludynamic parameters (peak pressure drop and minimum spouting velocity). In the wet experiments, distilled water was used as standard paste for being the constituent corresponding to $75 \%$ to $97 \%$ of the weight of real pastes. With knowledge from the previous steps, the drying of real pastes was done. According to Ochoa-Martinez et al. [8] and Nascimento et al. [7] the absence of fat in skimmed milk leads to difficulties in the circulation of the inert particles, accumulation of paste on the surface of inert particles, and consequently, an increase in the values of pressure drop. So, skimmed milk was used to show the potential improvement of drying with three different cone angles. In addition, a neural network was designed and trained with the data base to predict the minimum spouting velocity and the peak pressure drop on the spouted bed for the experimental conditions studied.

\section{Materials and Methods}

\subsection{Equipment and Operations Conditions}

The fluidynamics experiments were performed in a spouted bed consisting of an inox iron cylindrical vessel, with $120 \mathrm{~cm}$ of height, $30 \mathrm{~cm}$ of diameter, inlet diameter with $3 \mathrm{~cm}$ and three lower cone angles $\left(45^{\circ}, 60^{\circ}\right.$ and $75^{\circ}$ ). Figure 1 shows the schematic diagram of the experimental setup.

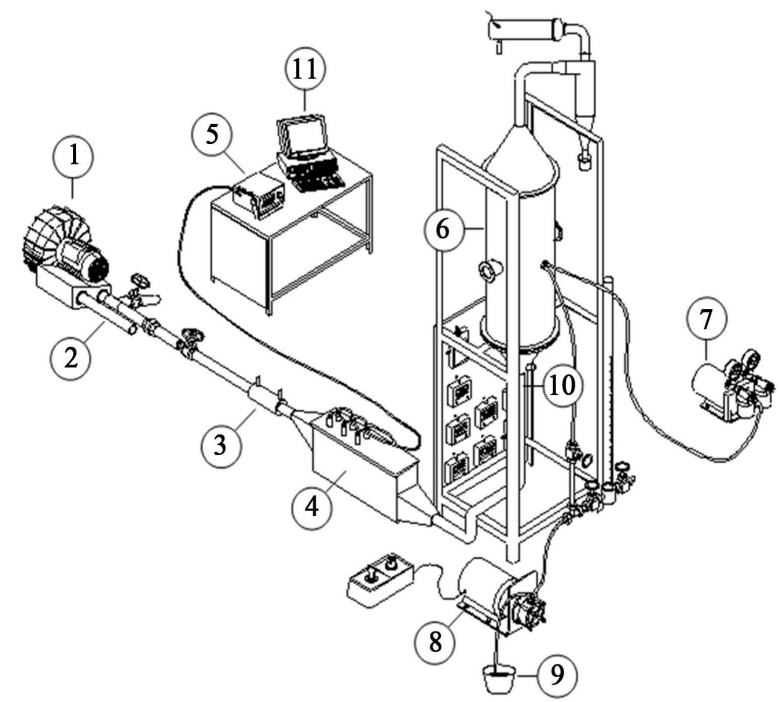

Figure 1. Schematic diagram of the experimental apparatus: (1) blower; (2) by-pass system; (3) Venture; (4) heat exchanger; (5) temperature controller; (6) drying chamber; (7) air compressor; (8) peristaltic pump; (9) paste reservoir; (10) inlet air nozzle; (11) acquisition unit. 
Figure 2 presents the bed specifications used in this study and the bed dimensions are presented in Table 1.

A Venture nozzle is employed, whose geometric factors are defined in Figure 3.

Polyethylene particles of $4.38 \mathrm{~mm}$ of diameter and $930.50 \pm 0.3 \mathrm{~kg} / \mathrm{m}^{3}$ of specific mass as inert particles were used in the experiments.

\subsection{Experimental Description}

Firstly the peak pressure drop characteristic and minimum spouting velocity in both conical and conical-cylindrical spouted beds were obtained based on the curve of the pressure drop versus the superficial air velocity from both increasing and decreasing the superficial air velocity, according to the methodology proposed by Mathur and Epstein [1]. The experimental operating conditions are summarized in Table 2. All measurements were triplicate in order to check the reproducibility of the data accuracy. The values of pressure drop are the measurements of empty bed pressure drop subtracted of the measurements of bed pressure drop with the load of particles.

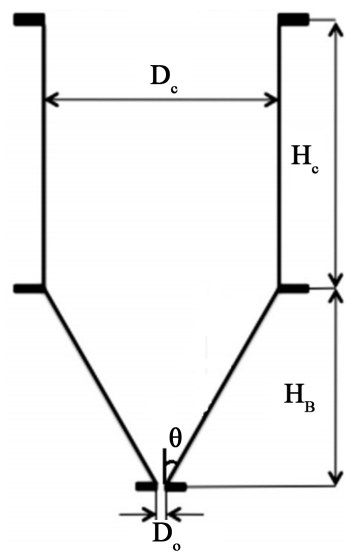

Figure 2. Bed specifications.

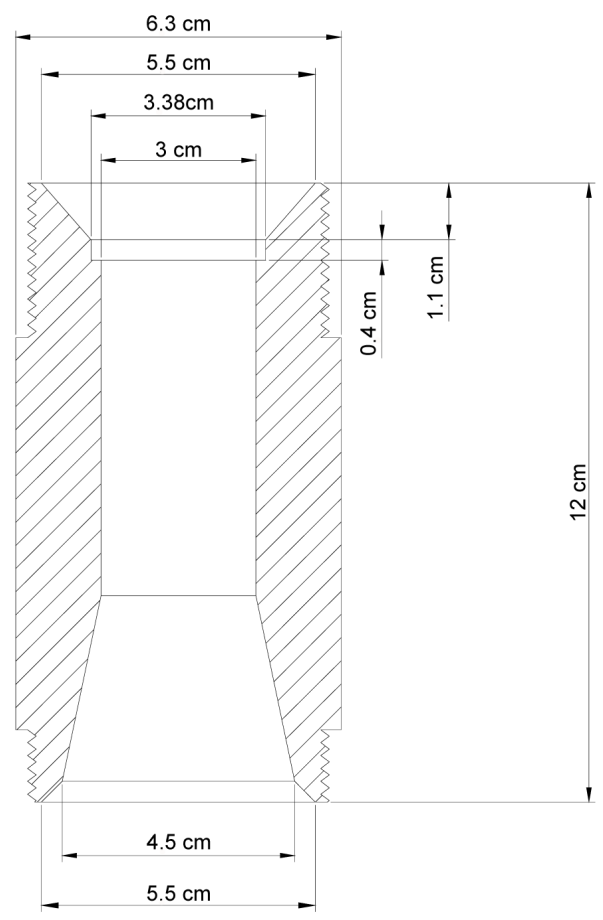

Figure 3. Inlet nozzle (Venture). 
Table 1. Bed dimensions.

\begin{tabular}{|c|c|c|c|c|}
\hline$\theta\left(^{\circ}\right)$ & $\mathrm{H}_{\mathrm{B}}(\mathrm{cm})$ & $\mathrm{D}_{\mathrm{c}}(\mathrm{cm})$ & $\mathrm{H}_{\mathrm{c}}(\mathrm{cm})$ & $\mathrm{D}_{0}(\mathrm{~cm})$ \\
\hline 45 & 28.70 & 30 & 120 & 3 \\
\hline 60 & 20.50 & 30 & 120 & 3 \\
\hline 75 & 16.50 & 30 & 120 & 3 \\
\hline
\end{tabular}

Table 2. Operating conditions.

\begin{tabular}{ccccc}
\hline Temperature $\left({ }^{\circ} \mathrm{C}\right)$ & $\theta\left(^{\circ}\right)$ & $\mathrm{m}_{\mathrm{p}}(\mathrm{kg})$ & $\mathrm{H}_{0}(\mathrm{~cm})$ & Bed configuration \\
\hline 100 & 45 & 1.50 & 18.00 & Conical \\
100 & 45 & 3.00 & 24.00 & Conical \\
100 & 45 & 4.50 & 28.70 & Conical \\
100 & 60 & 1.50 & 15.00 & Conical \\
100 & 60 & 3.00 & 20.00 & Conical \\
100 & 60 & 4.50 & 23.50 & Conical-cylindrical \\
100 & 75 & 1.50 & 13.00 & Conical \\
100 & 75 & 3.00 & 17.50 & Conical-cylindrical \\
100 & 75 & 1.50 & 21.00 & Conical-cylindrical \\
100 & 45 & 3.64 & 20.50 & Conical \\
100 & 60 & 3.84 & 20.50 & Conical \\
100 & 75 & & 20.50 & Conical-cylindrical \\
\hline
\end{tabular}

After that, the experiments that followed employed distilled water as standard paste in order to build an initial background on drying pastes. Finally, drying experiments using skimmed milk were carried out. Measurements of inlet air temperature and velocity, bed pressure drop, dry and wet bulb temperatures at the cyclone exhaust were available. Data was collected every 30 seconds by the acquisition system, 1024 points at a frequency of $500 \mathrm{~Hz}$. Dry and wet bulb temperature measurements were converted to relative humidity values of the exhaust air. The inlet air temperature and inlet air velocity were at $100^{\circ} \mathrm{C}$ and $1.30 \mathrm{u}_{\mathrm{mj}}$, respectively.

\subsection{Artificial Neural Networks}

An artificial neural network (RNA) was proposed to predict the minimum spout velocity, pressure drop on the spouted bed for different cone angles and load of inert particles. The RNA can represent non-linear processes with complex structures and, in some cases, provide better results than empirical correlations [9], they may be an interesting and promising alternative to estimate fluidynamics parameters for different bed configurations. Another advantage to be highlighted and that fits the approach of this study is that neural networks are a simple alternative for processes that involve phenomena which are complex and of difficult mathematical description.

The neural network was developed using Neural Network Toolbox in MATLAB 2007 software. This was a three layer feedforward neural network, with one single hidden layer, two inputs and two outputs as shown in Figure 4.

The number of neurons in the hidden layer was chosen by trial and error, as suggested by Himmelblau [9], starting with 2 neurons and adding up some more until the network performance in estimating the correct output is satisfactory. The number of neurons for this study was 3. Backpropagation was used as learning method.

\section{Results and Discussion}

\subsection{Minimum Spouting Velocity}

Figure 5 shows the values of minimum spout velocity as a function of cone angle obtained for polyethylene particles, different load of inert material. The air temperature was keep at $100^{\circ} \mathrm{C}$. It is seen in Figure 5 that, for the 


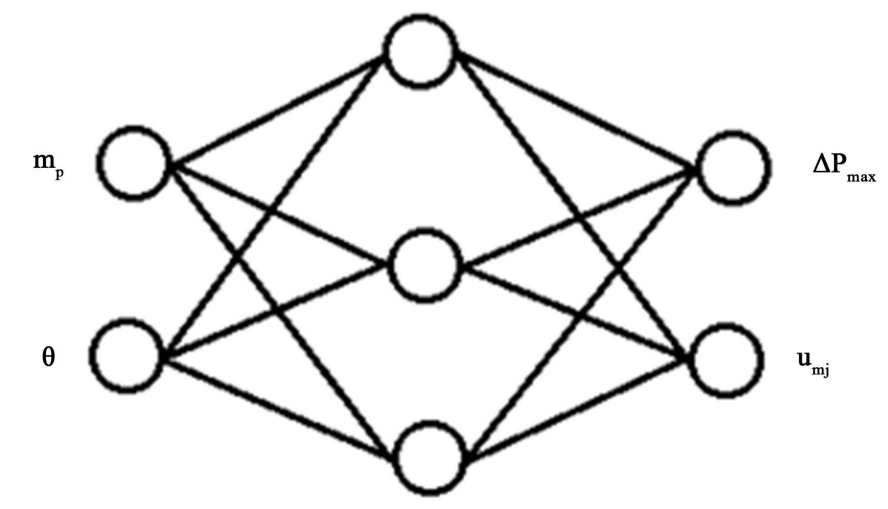

Figure 4. Schematic representation of the neural network used to estimate fludynamic parameters. Where, $\mathrm{m}_{\mathrm{p}}$ is the load of inert material, $\theta$ is the cone angles, $\mathrm{u}_{\mathrm{mi}}$ is the minimum spouting velocity and $\Delta \mathrm{P}_{\max }$ is the peak pressure drop.

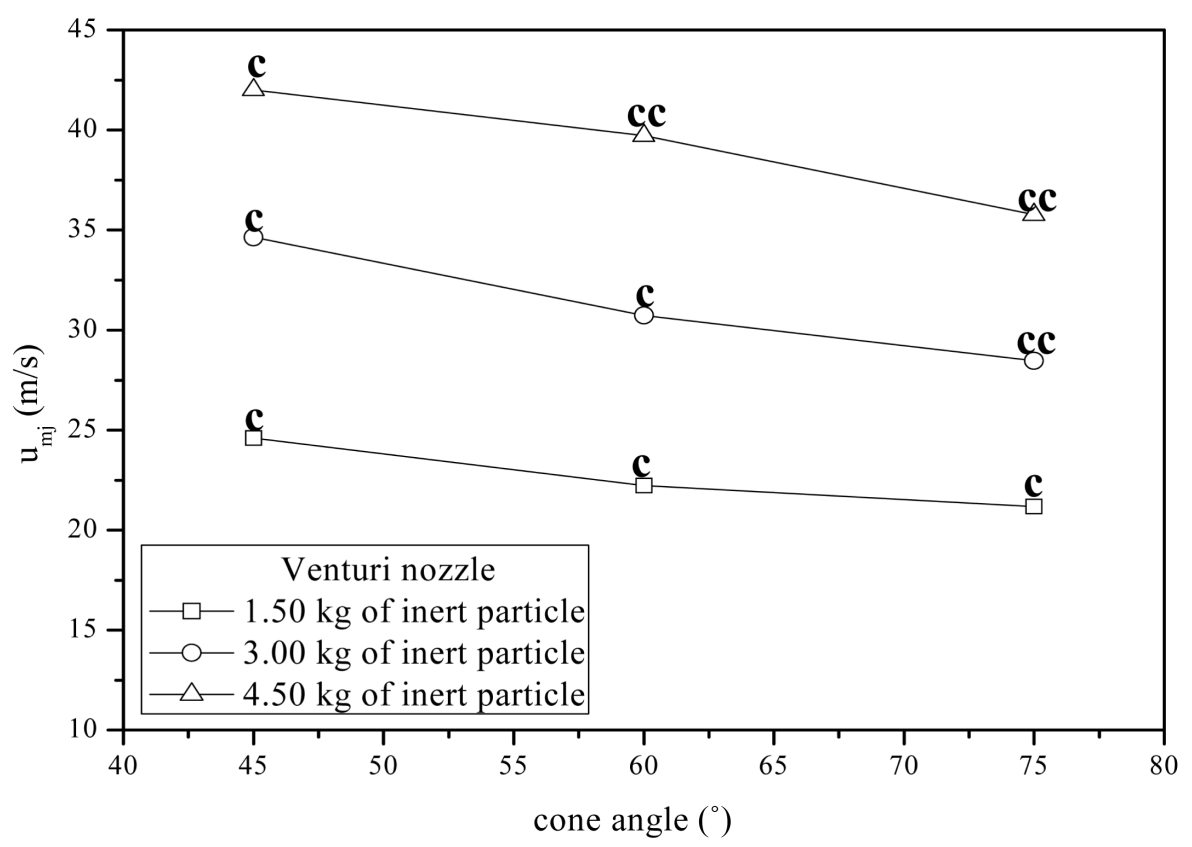

Figure 5. Minimum spout velocity as a function of cone angle obtained for different load of inert particle. ${ }^{*}$ c-conical spouted bed, ${ }^{* *}$ cc-conical cylindrical spouted bed.

operational conditions employed, the minimum spouting velocity was influenced by the cone angle $(\theta)$ and by the load of inert particle $\left(\mathrm{m}_{\mathrm{p}}\right)$. As it is seen in these results, a decrease in $\theta$ leads to higher values of $\mathrm{u}_{\mathrm{mj}}$ for all values of $m_{p}$ studied. This is due to the fact that for a fixed load of inert particles, increasing the cone angle decreases the static bed height, $\mathrm{H}_{0}$, (Figure 6) and, consequently, smaller air velocity is needed to support the spouted state. In agreement with these results, Mathur and Epstein [1] reported that the minimum spouting velocity depends on the solid characteristics, fluid properties and bed geometry. Mathur and Epstein [1] also observed that for conical-cylindrical spouted bed the intensity of cone angle effect depending of other variable, as example, column diameter, $\mathrm{D}_{\mathrm{c}}$.

Another aspect that should be analyzed is the influence of cone angle on the fluidynamic for fixed static bed height. Figure 7 presents the values of minimum spout velocity as a function of cone angle obtained for polyethylene particles, fixed static bed height and $100^{\circ} \mathrm{C}$.

It is shown in Figure 7 that $\mathrm{u}_{\mathrm{mj}}$ increases as $\theta$ is increased between $45^{\circ}$ to $60^{\circ}$, on the other hand, the minimum spouting velocity remains practically constant increases $\theta$ from $60^{\circ}$ to $75^{\circ}$. This is due to the fact that for a fixed static bed height (Table 2), increasing the cone angle from $45^{\circ}$ to $60^{\circ}$ the $\mathrm{m}_{\mathrm{p}}$ difference was higher than 

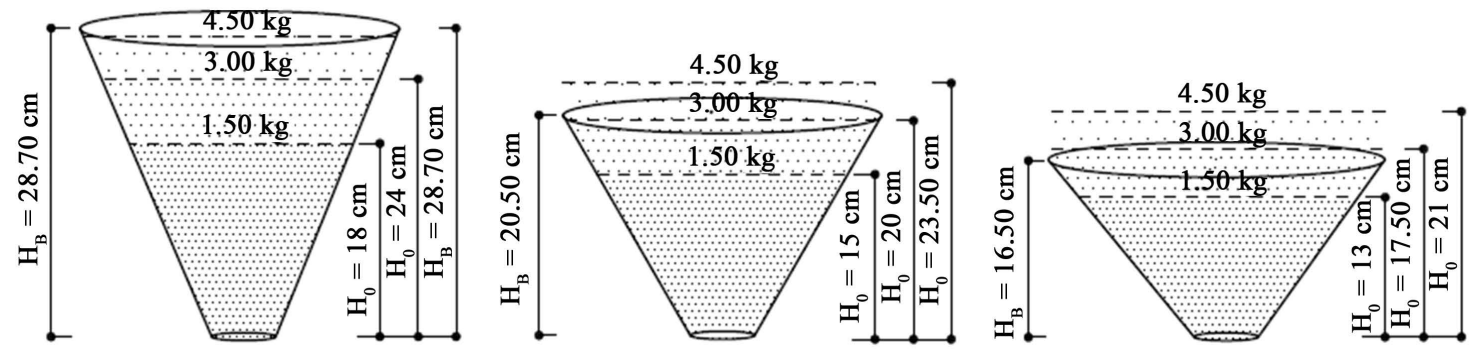

Figure 6. Static bed height for each base angle: (a) cone angle of $45^{\circ}$; (b) cone angle of $60^{\circ}$; (c) cone angle of $75^{\circ}$.

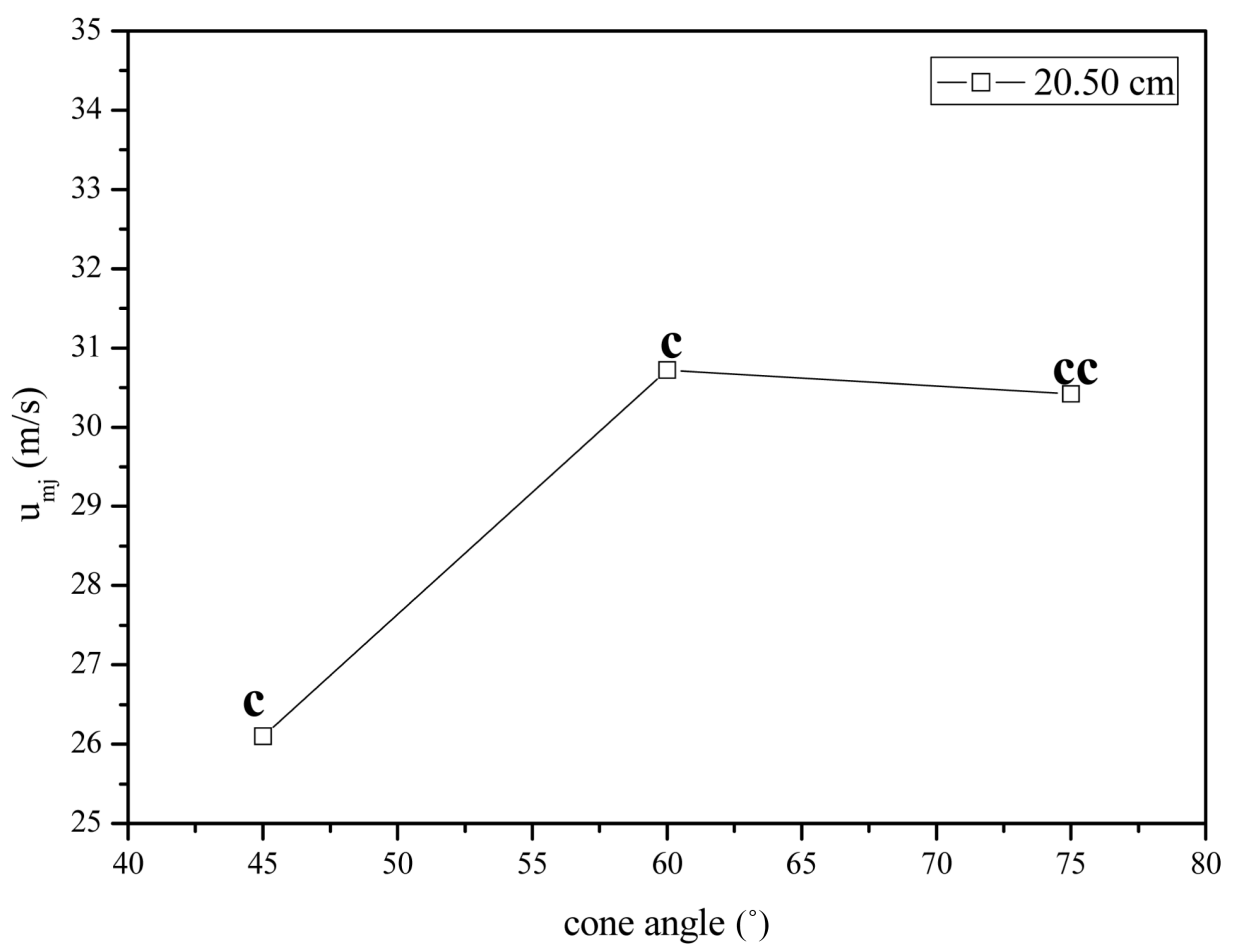

Figure 7. Minimum spouting velocity as a function of cone angle obtained for fixed static bed height. ${ }^{*}$ c-conical spouted bed, *** cc-conical cylindrical spouted bed.

varies cone angle form $60^{\circ}$ to $75^{\circ}, 1.36$ e $0.84 \mathrm{~kg}$, respectively. Thus, a higher air velocity is required to maintain spouting regime increasing $\theta$ from 45 to $60^{\circ}$.

Another aspect that must be taken into account is the bed configuration used. As one can observe in Figure 7 it was used two distinct bed configurations: conical and conical-cylindrical spouted bed. According to Wang et $a l$. [10], in conical spouted beds where the solids inventory is restrained within the conical region below the cylindrical section, the hydrodynamics of the conical spouted bed are quite different from that of the conventional cylindrical spouted beds. Kmiec [11] reported that the minimum spouting velocity in a conical spouted bed is more dependent on the bed height than the minimum spouting velocity in conical-cylindrical spouted beds. Mathur and Epstein [1] analyzed the data predict by the Mathur-Gisler Equation for different experimental data provided by literature for conical-cylindrical spouted bed bed. The authors observed that for columns up to 30.5 $\mathrm{cm}$ diameter the angle cone did not have significantly effect on the minimum spouting velocity. Although, in a $61 \mathrm{~cm}$ column, the spouting velocity for wheat was $10 \%$ higher with an $85^{\circ}$ cone than with a $45^{\circ}$ cone. It was also observed that the large column diameter, $D_{c}$, results were better correlated if the exponent to the ratio $\mathrm{D}_{\mathrm{i}} / \mathrm{D}_{\mathrm{c}}$ was reduced to 0.23 for $45^{\circ}$ and $60^{\circ}$ cone angles and to 0.13 for $85^{\circ}$. However, Olazar et al. [12] found that $\mathrm{D}_{\mathrm{c}}$ should not be used in the correlation to predict $\mathrm{u}_{\mathrm{mj}}$ in conical beds, because according to the authors this velocity will remain unchanged with variation in $\mathrm{D}_{\mathrm{c}}$ as long as the bed remains entirely in the conical section. 
Olazar et al. [2] conducted a study to delimit the application ranges of spouting regimes in conical contactors. The experiments were carried out with extension to solid of different characteristics, contactors with different geometry and with wide ranges of gas velocity. The authors found that particle diameter, $d_{p}$, had great effect, since there are restricted ranges of cone angles and inlet diameter for each values of $d_{p}$. This information indicates that this subject has to be treated with more care. The authors also observed that for high static bed height, the effect of the cone angle on the hydrodynamics it was more pronounced. Similar behavior was observed by Wang et al. [10].

\subsection{Peak Pressure Drop}

Figure 8 shows the values of peak pressure drop as a function of base angle obtained for polyethylene particles, different load of inert material and inlet air temperature of $100^{\circ} \mathrm{C}$. As observed in Figure 8, an increase in the cone angle decreases the peak pressure drop. As presented before in Figure 6 for a given $\mathrm{m}_{\mathrm{p}}$, a decrease in $\theta$ increases in static bed height, $\mathrm{H}_{0}$. Consequently, there is more air resistance and a higher pressure drop is required to break the bed and open the spout [13].

It was also observed that the effect of cone angle was less pronounced for $1.50 \mathrm{~kg}$ of inert particles. This is explained by the fact that was only used conical spouted bed and the $\mathrm{m}_{\mathrm{p}}$ variation between for all cone angles studied was very similar. However, for 3.00 and $4.50 \mathrm{~kg}$ of inert particle it was used conical and conical-cylindrical spouted bed as showed in Table 2. These results showed that for higher load of inert particles the effect of the bed configuration was more pronounced. According to Mathur and Epstein [1] and Moustoufi, Kulah and Koksal [14], the hydrodynamics of conical spouted beds is significantly different from that of conventional spouted beds.

Another aspect studied in this work was the influence of cone angle on fluidynamic parameters for fixed bed height. There is a conflict between the information provided by literature. According to Bi [15], the MukhlenovGorshtein [16] correlation predicts that $\Delta \mathrm{P}_{\text {máx }}$ increases with increasing cone angle for given static bed height. The opposite is predicted by the correlations of Gelperin et al. [17] and Olazar et al. [18]. Wang et al. [10] did not observe a clear effect of cone angle on $\Delta \mathrm{P}_{\text {máx }}$. In order to confirm this information, experiments were conducted using fixed static bed height and distinct cone angles, as shown in Figure 9.

Experimental evidences presented in Figure 9 demonstrate the effect of cone angle on the peak pressure drop. It was observed for a fixed bed height, an increase in $\theta$ leads higher values of $\Delta \mathrm{P}_{\text {máx. }}$ As shown in Table 2, for a fixed static bed height, the load of inert material increases as the cone angle is increased. Consequently, the

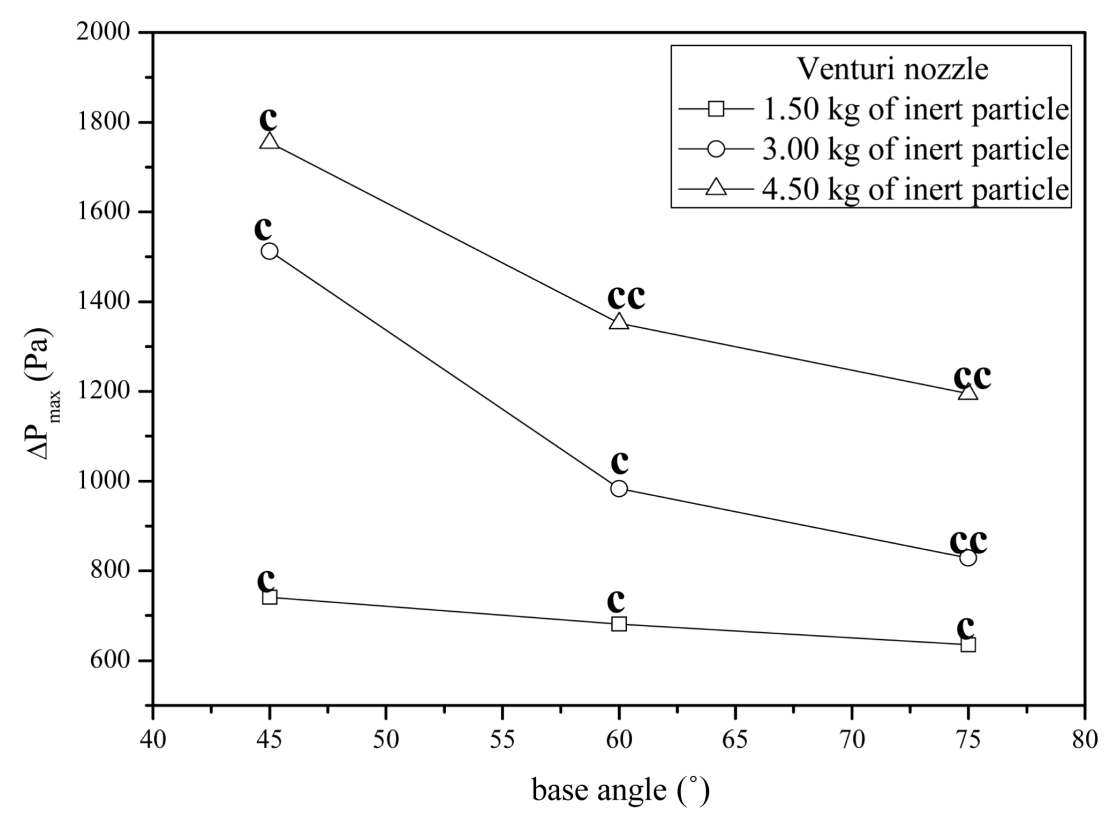

Figure 8. Peak pressure drop as a function of cone angle obtained for different load of inert particle. ${ }^{*}$ c-conical spouted bed, ${ }^{* *}$ cc-conical cylindrical spouted bed. 


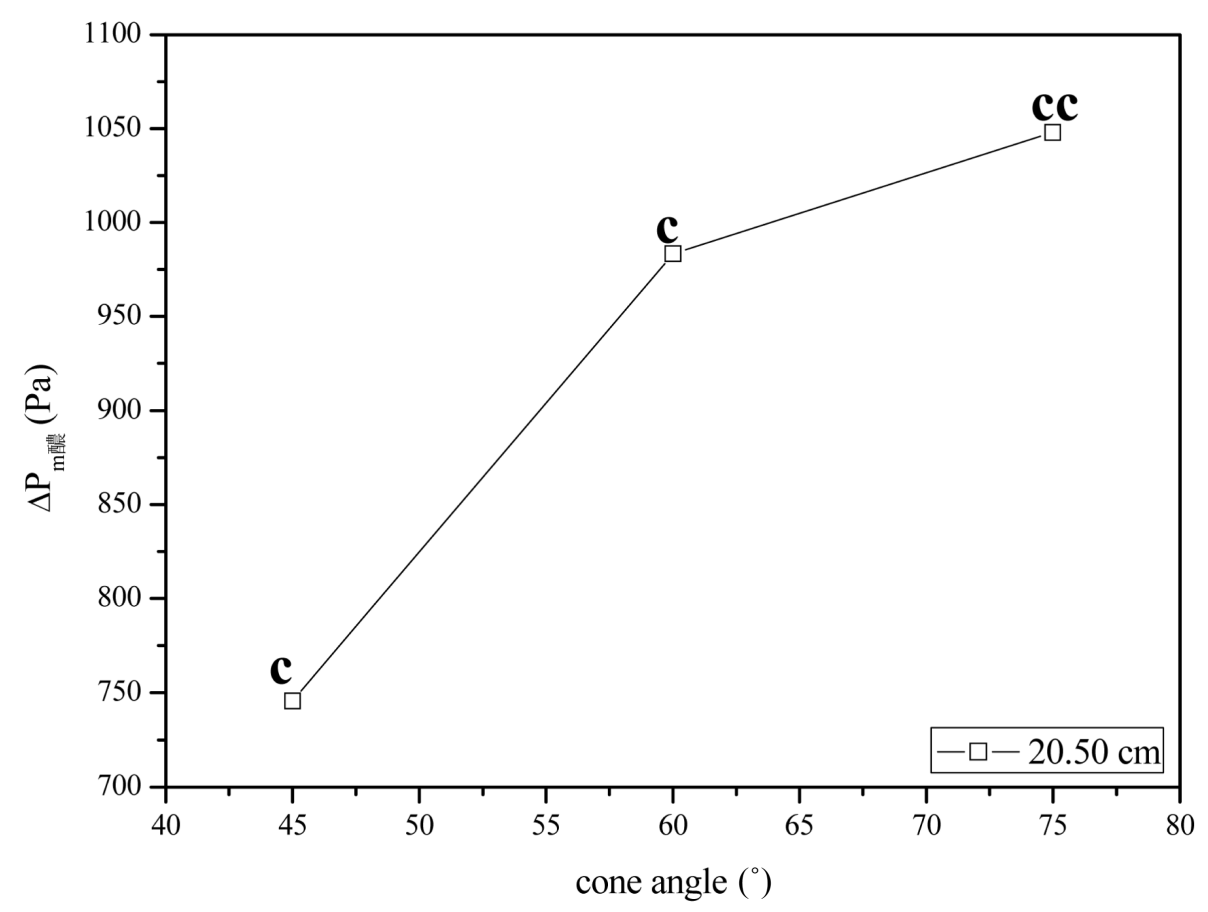

Figure 9. Peak pressure drop as a function of cone angle obtained for fixed static bed height *c-conical spouted bed, ${ }^{* *}$ cc-conical cylindrical spouted bed.

measured values of $\Delta \mathrm{P}_{\text {máx }}$ increases as the cone angles are increased. In the same way, it is observed that the effect of cone angle was more pronounced cone angles between $45^{\circ}$ to $60^{\circ}$ and 45 to $75^{\circ}$. Whereas for $\theta$ from 60 to $75^{\circ}$ the $\Delta \mathrm{P}_{\text {máx }}$ variation is very small, since the $\mathrm{m}_{\mathrm{p}}$ variation was not large to provoke a pronounced increase in $\Delta \mathrm{P}_{\text {máx. }}$. From Figure 9, it can be seen that the intensity of cone angle effect was dependent on the bed configuration.

The experimental results obtained in this work showed that the fluidynamic parameters of spouted bed were dependent on bed configuration, bed geometry and operating conditions. Thus, a confinable tool to predict the minimum spouting velocity and the peak pressure drop for different bed configuration is very useful and necessary.

\subsection{Neural Network}

A neural network model was designed from experimental data to predict the minimum spouting velocity and peak pressure on the spouted bed for different cone angles and load of inert particle. Figure 10(a) and Figure 10(b) show the values of fluidynamic parameters provided by the neural networks and experimentally data obtained.

As observed in Figure 10(a) and Figure 10(b), predictions by the neural network agree well with the experimental data, once the predicted values were close to $45^{\circ}$ line. The results presented in Figure 10(a) and Figure 10(b) indicates that the RNA is useful method for predicting minimum spouting velocity and peak pressure drop of conical and conical-cylindrical spouted beds.

Neural network proposed in this work was trained and evaluated with experimental data for $u_{m j}(30.72 \mathrm{~m} / \mathrm{s})$ and $\Delta \mathrm{P}_{\text {máx }}(983.51 \mathrm{~Pa})$ and it was obtained the respective values for $\mathrm{u}_{\mathrm{mj}}(30.70 \mathrm{~m} / \mathrm{s})$ and for $\Delta \mathrm{P}_{\text {máx }}(1027.60 \mathrm{~Pa})$. It was observed that the network fitted best the measured values of minimum spouting velocity, since the error provided by the network is close to the experimental error.

\subsection{Water Evaporation}

The information obtained and discussed in the previous section were essential for to initiate the experimental runs using distilled water. Table 3 shows the maximum capacity for evaporation water obtained from experimental measured for stable conditions. 


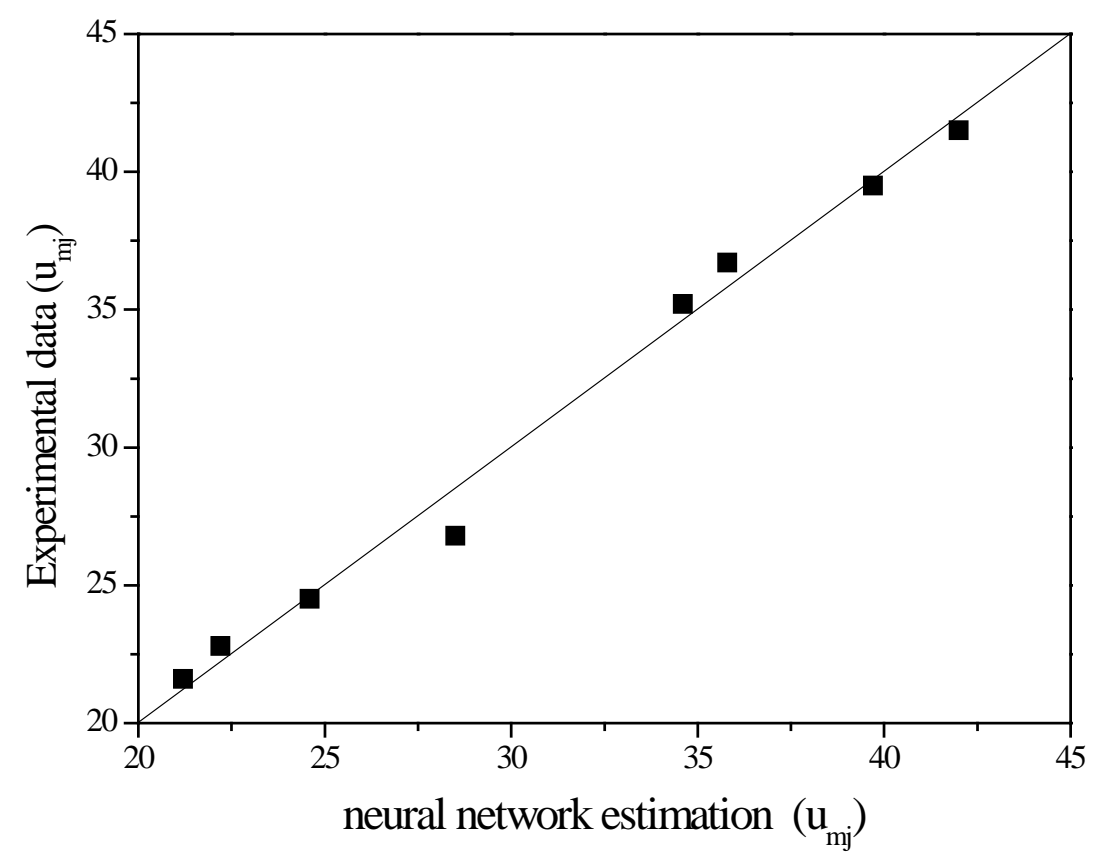

(a)

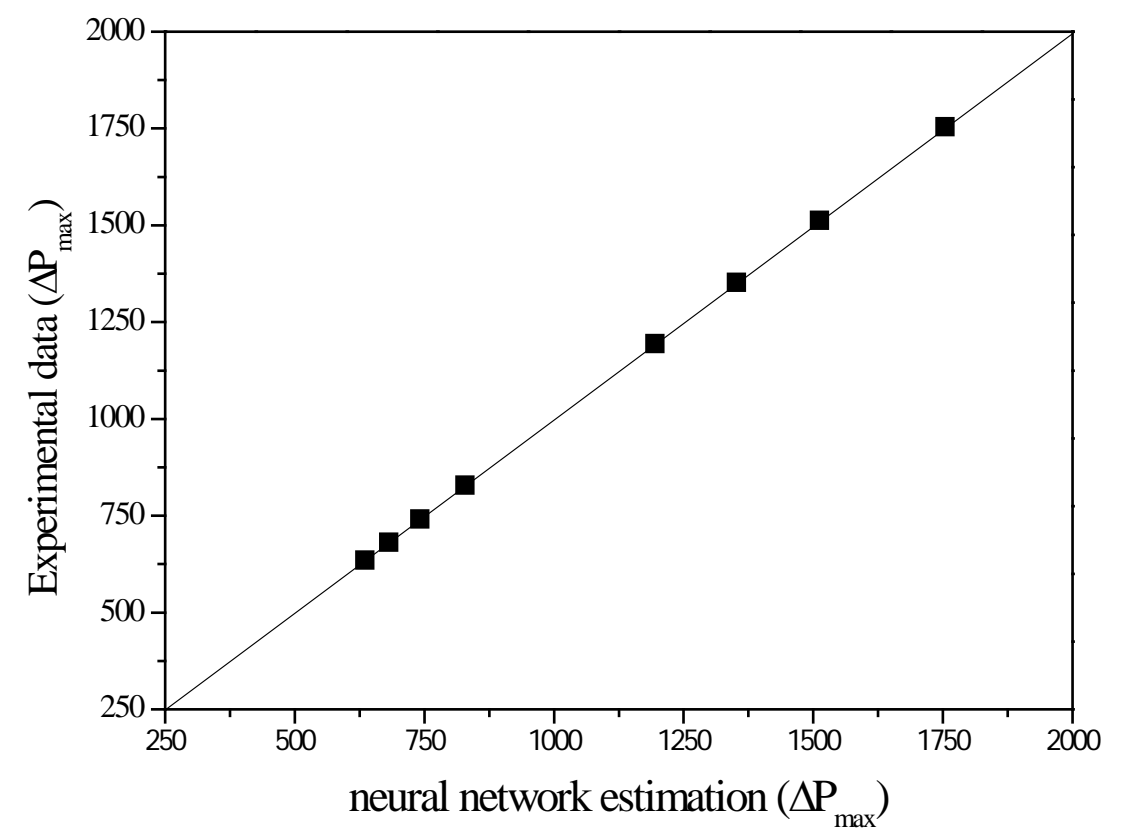

(b)

Figure 10. Experimental and estimated data for the neural network: (a) $\mathrm{u}_{\mathrm{mj}}$; (b) $\Delta \mathrm{P}_{\max }$.

Experimental investigation showed that the effect of $\mathrm{m}_{\mathrm{p}}$ on maximum capacity for evaporation water, $\mathrm{Q}$, was more pronounce than $\theta$. As previously mentioned by Almeida et al. [19] the load of inert particles had a strong influence on the maximum allowable feed flow rate. This is because an increase in $\mathrm{m}_{\mathrm{p}}$ increases the specific area of the bed. So, as evaporation occurs on the particles surface, an increase in the specific area increases the evaporation rate.

Referring to the effect of cone angle on maximum capacity for evaporation water, it was observed that Q had only an improvement of $5 \mathrm{ml} / \mathrm{min}$. as $\theta$ varies from $75^{\circ}$ to $60^{\circ}$ or $75^{\circ}$ to $45^{\circ}$ for both load of inert particle available. Rodrigues [20] studied the effect of the cone angle on the maximum capacity for evaporating water. The 
author observed that the rate of water evaporation per unit of inert solid volume increases as $\theta$ varies from 60 to $30^{\circ}$. It is also verified that the annulus aeration improves as $\theta$ decreases. However, this information cannot be compared, since the author used fixed bed height. So the author assigned this behavior to the fact that a higher in $\theta$ implies increasing in $\mathrm{m}_{\mathrm{p}}$, which consequently increases $\mathrm{Q}$. It is noted that there is insufficient information about the effect of cone angle on maximum capacity for evaporation water mainly drying pastes provided by literature. The most researches analyze the inference of bed geometry of dry bed.

Referring to the effect of water on the fluidynamic behavior, Figure 11 shows the dimensionless bed pressure drop as a function of time for $100^{\circ} \mathrm{C}, 1.30 \mathrm{u}_{\mathrm{mj}}, 4.50 \mathrm{~kg}$ of inert particles and cone angle of $60^{\circ}$.

As Figure 11 shows the dimensionless bed pressure drop practically did not change for feed flow rates below $50 \mathrm{ml} / \mathrm{min}\left(\Delta \mathrm{P}_{\mathrm{t}} / \Delta \mathrm{P}_{\mathrm{t}=\mathrm{o}}\right.$ close to 1$)$. However, it decreased for feed flow rates above $55 \mathrm{ml} / \mathrm{min}$. Similar results have been reported by Patel et al. [21], Schneider and Bridgwater [22], Almeida et al. [19] and Bitti et al. [23]. According to the abovementioned authors less air passes through the annulus as the amount of paste fed to the dryer is increased. The air main stream goes through the spout channel, reducing, in this way, the bed pressure drop. Another possible way to understand this phenomenon is that the presence of a liquid phase increases particle agglomeration, slowing down particle motion in the annulus. The same behavior was also observed for the other cone angles studied.

\subsection{Drying of Skimmed Milk}

Based on experimental results presented in Table 3, Q was obtained for $4.50 \mathrm{~kg}$ for all cone angles used. Thus, the drying experiments using skimmed milk were conducted for $4.50 \mathrm{~kg}, 1.30 \mathrm{u}_{\mathrm{mj}}, 100^{\circ} \mathrm{C}$ and different cone angles. Figures 12(a)-(c) show the dimensionless bed pressure drop as a function of time for cone angles of $45^{\circ}$, $60^{\circ}$ and $75^{\circ}$, respectively.

Despite cone angles did not had great effect on maximum capacity to evaporating water, Figures 12(a)-(c) showed the effect of dimensionless pressure drop during skimmed milk drying. By comparing Figures 12(a)-(c) it became clear that for the same operating conditions the dimensionless pressure drop had different behavior for $\theta=60^{\circ}$. The dimensionless pressure drop deviated from the straight line corresponding to $\Delta \mathrm{P}_{\mathrm{t}} / \Delta \mathrm{P}_{\mathrm{t}=\mathrm{o}}=1$ for feed flow rates varying from 10 to $35 \mathrm{ml} / \mathrm{min}$. Values of dimensionless pressure drop were higher than one for most feed flow rates employed. Similar behavior has been reported by Almeida et al. [19] and Nascimento et al. [7].

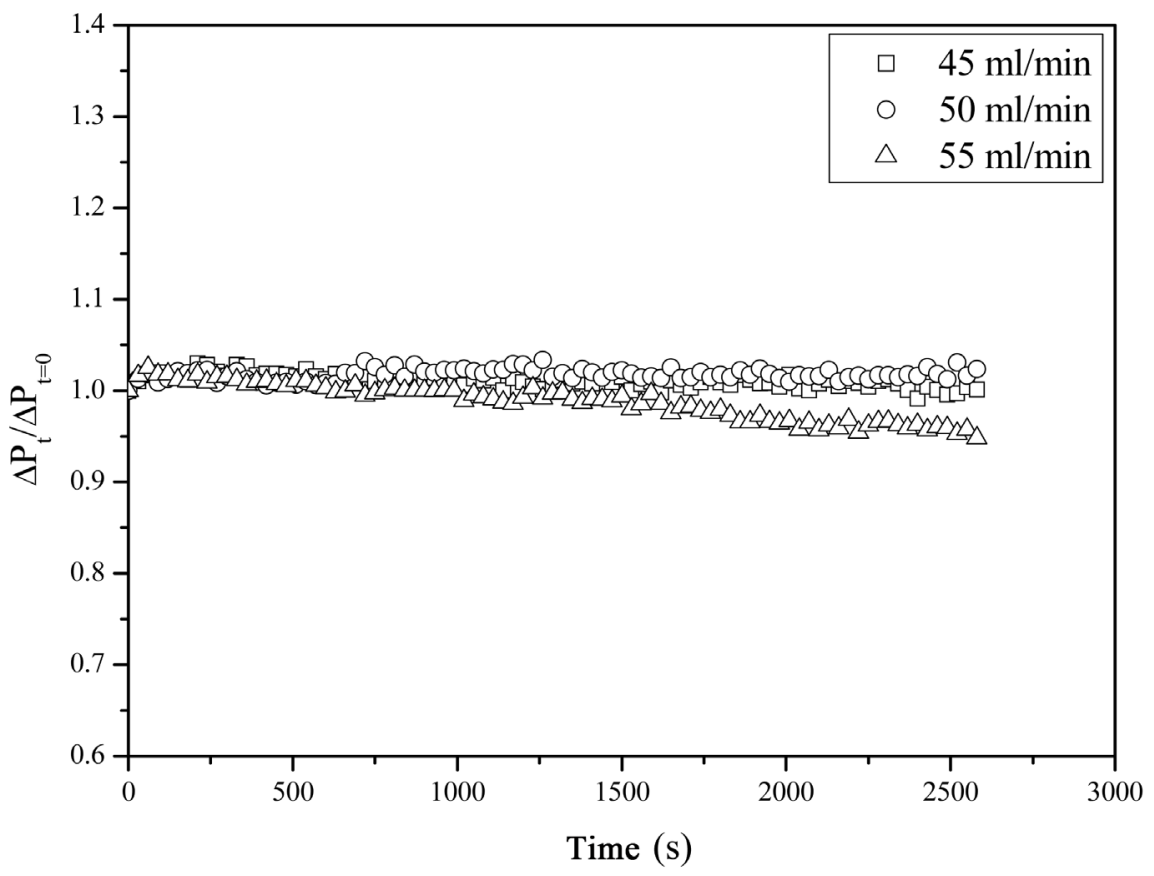

Figure 11. Dimensionless pressure drop as a function of time for $\mathrm{T}=100^{\circ} \mathrm{C}, \mathrm{mp}=4.5 \mathrm{~kg}$ and $\theta=$ $60^{\circ}$, parametrizing Q. 


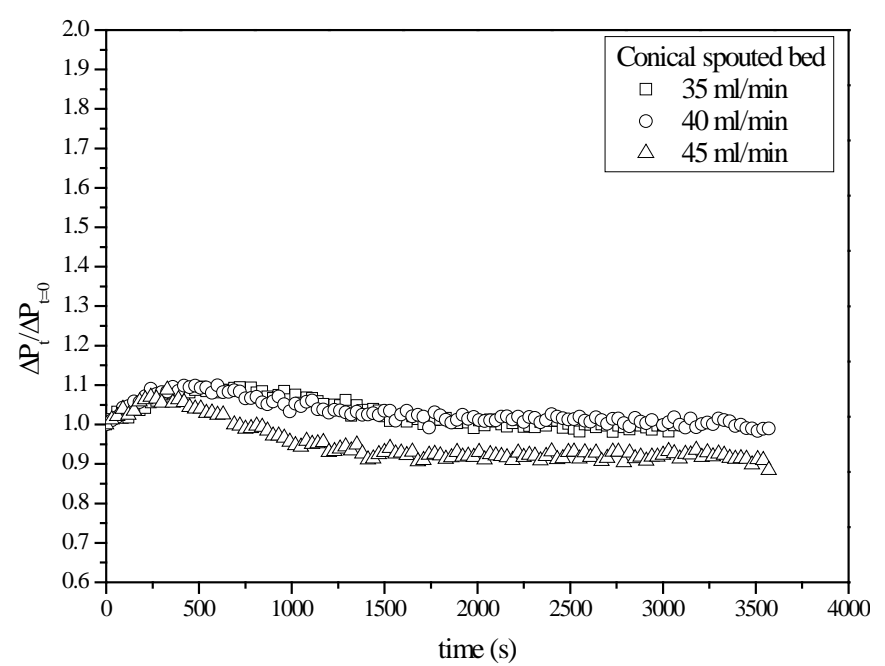

(a)

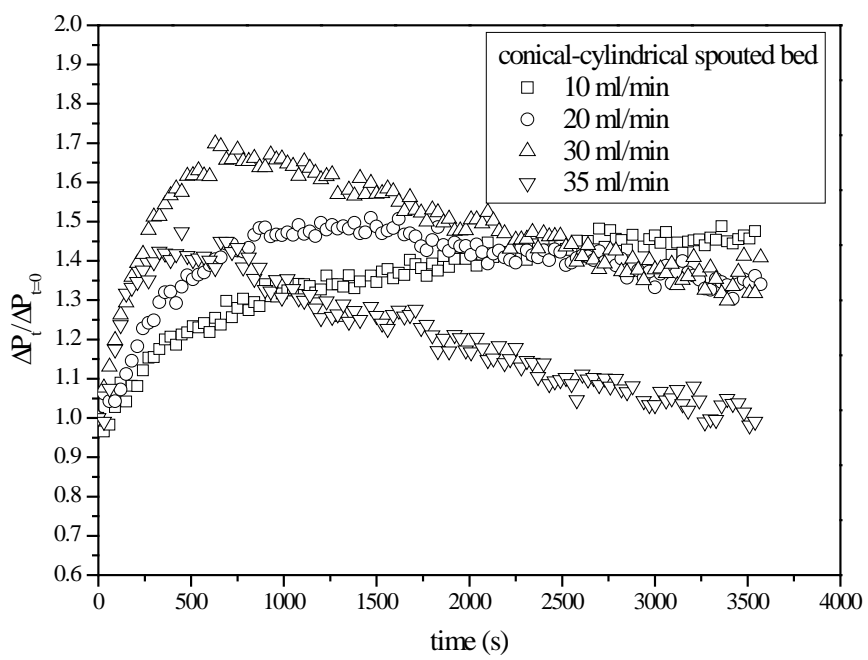

(b)

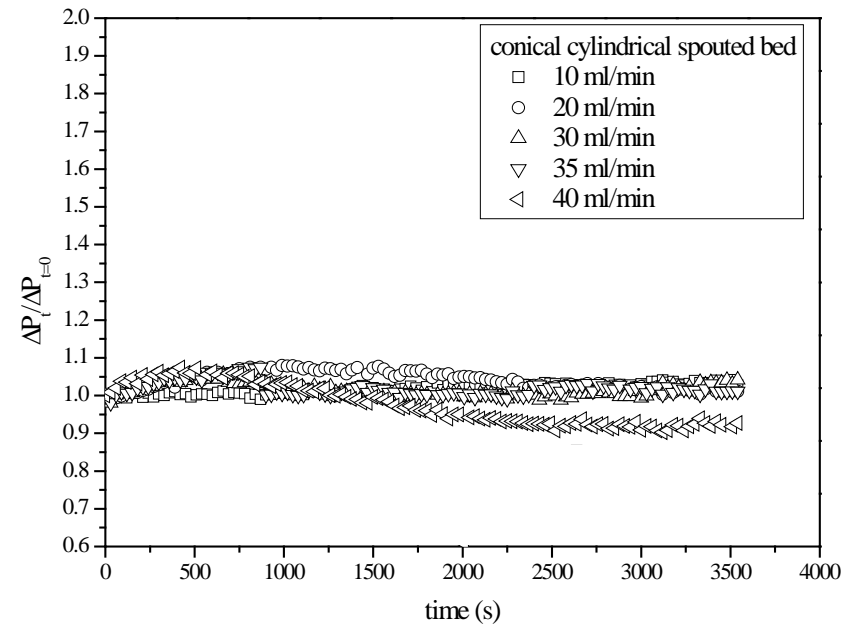

(c)

Figure 12. Dimensionless pressure drop as a function of time, parametrizing $\mathrm{Q}_{\mathrm{sm}}$ : (a) cone angle of $45^{\circ}$; (b) cone angle of $60^{\circ}$ and (c) cone angle of $75^{\circ}$. 
Table 3. Maximum allowable water feed flow rates for different cone angles, $1.3 \mathrm{u}_{\mathrm{mj}}$ and $100^{\circ} \mathrm{C}$.

\begin{tabular}{ccc}
\hline$\theta\left(^{\circ}\right)$ & $\mathrm{m}_{\mathrm{p}}(\mathrm{kg})$ & $\mathrm{Q}(\mathrm{mL} / \mathrm{min})$ \\
75 & 3.00 & 35 \\
60 & 3.00 & 40 \\
45 & 3.00 & 40 \\
75 & 4.50 & 50 \\
60 & 4.50 & 50 \\
45 & 4.50 & 50 \\
\hline
\end{tabular}

Comparing these figures was noteworthy that the dimensionless bed pressure drop practically did not change for feed flow rates below $45 \mathrm{ml} / \mathrm{min}\left(\Delta \mathrm{P}_{\mathrm{t}} / \Delta \mathrm{P}_{\mathrm{t}=\mathrm{o}}\right.$ close to 1$)$ for $45^{\circ}$ and $40 \mathrm{ml} / \mathrm{min}$ for $75^{\circ}$. However, it decreased for feed flow rates above 45 and $40 \mathrm{ml} / \mathrm{min}$ for cone angles 45 and $75^{\circ}$, respectively. Similar results have been reported using water as paste by Almeida et al. [19], Patel et al. [21], Schneider and Bridgwater [22] and Bitti et al. [23].

The experimental evidences indicated that dimensionless pressure drop for skimmed milk had similar behavior when it was used distilled water for cone angles of $45^{\circ}$ and $75^{\circ}$, as observed comparing Figure 11, Figure 12(a) and Figure 12(c). One can be said that the bed did not "feel" the presence of the paste. However, it was also observed that the feed flow rate of skimmed milk was smaller than water, as shown in Table 4. Similar results have been reported by Almeida et al. [19] and Nascimento et al. [7].

An aspect that must be taken into account is the bed configuration used in this work (conical and conical-cylindrical spouted bed). According to Olazar et al. [12], for conical spouted beds, cone angles higher than $60^{\circ}$ are not recommended because the solid circulation rate is very low. Elperin et al. [24] reported that a cone angle of $40^{\circ}-45^{\circ}$ was the optimum for maximizing solids circulation rate. Thus, the stable values of $\Delta \mathrm{P}_{\mathrm{t}} / \Delta \mathrm{P}_{\mathrm{t}=0}$ for conical spouted bed and cone angle of $45^{\circ}$ can be related to the high circulation of the inert particles, which minimized the effect of paste adhesion as related by Nascimento et al. [7]. On the other hand, the lower limit of cone angle for conical beds is $28^{\circ}$, as the bed is unavoidably unstable for lower angles [12].

The high values of dimensionless pressure drop using cone angle of $60^{\circ}$ can be a consequence of dead zone (zone of stagnant solids) that is formed near the inlet orifice for high values of cone angles [25]-[27]. Moreover, the absence of fat in skimmed milk provokes difficults in the particles circulation [7]. The dead zone reduces solid circulation and is not recommended for drying of pastes. However, Figure 12(c) showed that cone angle of $75^{\circ}$ was more stable than $60^{\circ}$ (Figure 12(b)). In both cases it was used conical-cylindrical spouted beds. According to Mathur and Epstein [1] for conical-cylindrical beds, an increase in cone angle leads increases in the cross flow rate in the upper region of the bed. Thus, there was more solid circulation using the cone angle of $75^{\circ}$, which favored the drying of skimmed milk.

The analysis of the three steps: fludynamic without paste, water evaporation and drying paste showed that the spouted bed technique was complex and one should be taken into account several factors to understand them. For instance, cone angle had not great effect on fludynamic using water, although it was observed a significant inference by using a real paste (skimmed milk).

\section{Conclusions}

From the results of this study, it was found that fluidynamic parameters and maximum capacity of water evaporation were influenced by both cone angles and load of inert particle in the range of operating conditions analysed. It was also found that the effect of load of inert material on water evaporation was more pronounced than cone angle. The neural network was a good tool for prediction when you had a data bank.

Drying experiments showed that the cone angle had significant effect on the dimensionless pressure drop. The evidences show that a conical spouted bed with cone angle of $45^{\circ}$ is recommended to drying skimmed milk. 
Table 4. Maximum flow rate of distilled water and skimmed milk in spouted bed: $1.30 \mathrm{u}_{\mathrm{mj}}, 100^{\circ} \mathrm{C}$.

\begin{tabular}{cccc}
\hline$\theta\left({ }^{\circ}\right)$ & $\mathrm{m}_{\mathrm{p}}(\mathrm{kg})$ & $\mathrm{Q}(\mathrm{mL} / \mathrm{min})$ & $\mathrm{Q}_{\mathrm{sm}}(\mathrm{mL} / \mathrm{min})$ \\
75 & 4.50 & 45 & 35 \\
60 & 4.50 & 50 & 30 \\
45 & 4.50 & 50 & 40 \\
\hline
\end{tabular}

\section{Acknowledgements}

The authors thank CNPq (Conselho Nacional de Desenvolvimento Científico e Tecnológico) for the financial support.

\section{References}

[1] Mathur, K.B. and Epstein, N. (1974) Spouted Beds. Academic Press, New York.

[2] Olazar, M., San José, M.J., Aguayo, A.T., Arandes, J.M. and Bilbao, J. (1992) Stable Operation Conditions for GasSolid Contact Regimes in Conical Spouted Beds. Industrial \& Engineering Chemical Research, 31, 1784-1792. http://dx.doi.org/10.1021/ie00007a025

[3] Olazar, M., San José, M.J., Izquierdo, M.A., Alvarez, S. and Bilbao, J. (2004) Fountain Geometry in Shallow Spouted Beds. Industrial \& Engineering Chemical Research, 43, 1163-1168. http://dx.doi.org/10.1021/ie030641d

[4] San José, M.J., Olazar, M., Izquierdo M.A., Alvarez, S. and Bilbao, J. (2004) Solid Trajectories and Cycle Times in Spouted Beds. Industrial \& Engineering Chemical Research, 43, 3433-3438. http://dx.doi.org/10.1021/ie030668x

[5] Pham, Q.T. (1983) Behavior of a Conical Spouted-Bed Dryer for Animal Blood. The Canadian Journal of Chemical Engineering, 61, 426-434. http://dx.doi.org/10.1002/cjce.5450610325

[6] Medeiros, M.F.D. , Rocha, S.C.S., Alsina, O.L.S. , Jerônimo, C.E.M. , Medeiros, U.K.L. and da Mata, A.L.M.L. (2002) Drying of Pulps of Tropical Fruits in Spouted Bed: Effect of Composition on Dryer Performance. Drying Technology, 20, 855-881. http://dx.doi.org/10.1081/DRT-120003767

[7] Nascimento, B.S., Freire, F.B. and Freire, J.T. (2013) Moisture Prediction during Paste Drying in a Spouted Bed. Drying Technology, 31, 1808-1816. http://dx.doi.org/10.1080/07373937.2013.825627

[8] Ochoa-Martinez, L.A., Brennan, J.G. and Niranjan, K. (1993) Spouted Bed Dryer for Liquid Foods. Food Control, 4, 41-45. http://dx.doi.org/10.1016/0956-7135(93)90126-9

[9] Himmelblau, D.M. (2008) Accounts of Experiences in the Application of Artificial Neural Networks in Chemical Engineering. Industrial \& Engineering Chemical Research, 47, 5782-5796. http://dx.doi.org/10.1021/ie800076s

[10] Wang, Z.G., Bi, H.T., Lim, C.J. and Su, P.C. (2004) Determination of Minimum Spouting Velocities in Conical Spouted Beds. The Canadian journal of Chemical Engineering, 82, 11-19. http://dx.doi.org/10.1002/cjce.5450820103

[11] Kmiec, A. (1983) The Minimum Spouting Velocity in Conical Beds. The Canadian Journal of Chemical Engineering, 61, 274-280. http://dx.doi.org/10.1002/cjce.5450610304

[12] Olazar, M., San José, M.J. and Bilbao, J. (2011) Conical Spouted Beds. In: Epstein, N. and Grace, J.R., Eds., Spouted and Spouted-Fluid Beds: Fundamentals and Applications, Cambridge University Press Co., New York, 82-104.

[13] Altzibar, H., Lopez, G., Bilbao, J. and Olazar, M. (2014) Operating and Peak Pressure Drops in Conical Spouted Beds Equipped with Draft Tubes of Different Configuration. Industrial \& Engineering Chemical Research, 53, 415-427. http://dx.doi.org/10.1021/ie402031t

[14] Moustoufi, N., Kulah, G. and Koksal, M. (2015) Flow Structure Characterization in Conical Spouted Beds Using Pressure Fluctuation Signals. Powder Technology, 269, 392-400. http://dx.doi.org/10.1016/j.powtec.2014.09.028

[15] Bi, X. (2011) Initiation of Spouting. In: Epstein, N. and Grace, J.R., Eds., Spouted and Spouted-Fluid Beds: Fundamentals and Applications, Cambridge University Press Co., New York, 17-28.

[16] Mukhlenov, I.P. and Gorshtein, A.E. (1965) Investigation of a Spouted Bed. Khimicheskaya Promyshlennost, 41, 443-446.

[17] Gelperim, N.I., Ainshtein, V.G. and Timokhova, L.P. (1961) Hydrodynamic Features of Fluidization of Granular Materials in Conical Sets. Khimicheskoe i Neftyanoe Mashinostroenie, 4, 12.

[18] Olazar, M., San José, M.J., Aguayo, A.T., Arandes, J.M. and Bilbao, J. (1993) Pressure Drop in Conical Spouted Beds. The Chemical Engineering Journal, 51, 53-60. http://dx.doi.org/10.1016/0300-9467(93)80008-C

[19] Almeida, A.R.F., Freire, F.B. and Freire, J.T. (2010) Transient Analysis of Pasty Material Drying in a Spouted Bed of 
Inert Particles. Drying Technology, 28, 330-340. http://dx.doi.org/10.1080/07373931003627189

[20] Rodrigues, C.C. (1993) Analysis of Drying of Suspensions in Spouted Bed with Inert Particles. MSC Dissertation, Federal University of São Carlos, São Carlos. (In Portuguese)

[21] Patel, K., Bridgwater, J., Baker, C.G. and Schneider, T. (1986) Spouting Behavior of Wet Solids. In: Mujumdar, A.S. and Roques, M.A., Eds., Drying'86, Hemisphere Publishing Corporation, New York, 183-189.

[22] Schneider, T. and Bridgwater, J. (1993) The Stability of Wet Spouted Beds. Drying Technology, 11, $277-301$. http://dx.doi.org/10.1080/07373939308916820

[23] Bitti, M.T., Perazzini, H., Freire, F.B. and Freire, J.T. (2012) Analysis of the Influence of Operating Conditions on the Evaporation Rate of Water during Drying in a Spouted Bed. Proceedings of 18th International Drying Symposium, Xiamen, 11-15.

[24] Elperin, I.T., Zabrodsky, S.S., Yefremtsev, V.S. and Mikhailik, V.D. (1967) On the Best Construction of Sets for Spouting Beds. Collected Papers on "Intensification on Transfer of Heat and Mass in Drying and Thermal Processes", Nauka I Tekhnika BSSR, Minsk, 323.

[25] Lim, C.J. and Grace, J.R. (1987) Spouted Bed Hydrodynamics in a 0.91 m Diameter Vessel. Canadian Journal Chemical Engineering, 65, 366-372. http://dx.doi.org/10.1002/cjce.5450650303

[26] He, Y.-L., Lim, C.J. and Grace, J.R. (1992) Spouted Bed and Spout-Fluid Bed Behaviour in a Column of Diameter $0.91 \mathrm{~m}$. The Canadian Journal of Chemical Engineering, 70, 848-857. http://dx.doi.org/10.1002/cjce.5450700505

[27] San José, M.J., Olazar, M., Llamosas, R., Izquierdo, M.A. and Bilbao, J. (1996) Study of Dead Zone and Spout Diameter in Shallow Spouted Beds of Cylindrical Geometry. The Chemical Engineering Journal, 64, 353-359.

\section{Nomenclature}

\begin{tabular}{|c|c|c|}
\hline $\mathrm{D}_{0}$ & Diameter of the inlet & $\mathrm{cm}$ \\
\hline $\mathrm{D}_{\mathrm{c}}$ & Diameter of the column & $\mathrm{cm}$ \\
\hline $\mathrm{D}_{\mathrm{i}}$ & Diameter of the bed bottom & $\mathrm{cm}$ \\
\hline $\mathrm{H}_{0}$ & Static bed height & $\mathrm{cm}$ \\
\hline $\mathrm{H}_{\mathrm{B}}$ & Cone height & $\mathrm{cm}$ \\
\hline $\mathrm{H}_{\mathrm{c}}$ & Column height & $\mathrm{cm}$ \\
\hline $\mathrm{m}_{\mathrm{p}}$ & Load of inert & $\mathrm{kg}$ \\
\hline $\mathrm{P}_{\text {máx }}$ & Peak pressure drop & $\mathrm{Pa}$ \\
\hline Q & Maximum feed flow rate of distilled water & $\mathrm{mL} / \mathrm{min}$ \\
\hline $\mathrm{Q}_{\mathrm{sm}}$ & Maximum feed flow rate of skimmed milk & $\mathrm{mL} / \mathrm{min}$ \\
\hline $\mathrm{u}_{\mathrm{mj}}$ & Minimum spouting velocity & $\mathrm{m} / \mathrm{s}$ \\
\hline
\end{tabular}

\section{Greek Letters}

$\theta$

$\Delta$
Cone angle

Difference 